\title{
A Sticking Point in Assessing Bacterial Contamination: Adhesive Characters of Bacterial Specializations, Swab Features, and Fomite Surface Properties Skew Colony Counts
}

\author{
Vicki Abrams Motz ${ }^{1 *}$ (D) , Linda Mull Young ${ }^{1}$, Meredith E. Motz ${ }^{2}$ and Suzanne C. Young ${ }^{3}$ \\ ${ }^{1}$ Department of Biological and Allied Health Science, Ohio Northern University, 525 South Main St., Ada, OH 45810, \\ United States. 'Innovation Center at Southern New Hampshire University, 2500 N. River Rd., Manchester, NH \\ 03101, United States. ${ }^{3}$ ProMedica Toledo Children's Hospital, 2142 N. Cove Blvd., Toledo, OH 43606, United States.
}

\begin{abstract}
Relative bacterial load as assessed by swabbing of surfaces is used to make critical decisions about safety in medical, food and athletic venues, with little consideration of bacterial attachment features (capsules, pili, flagella), swab type, or adhesive properties of fomites. To consider the impact of these parameters, a known quantity of bacteria with different adhesive specializations was applied to fomites of varying topography and surface energy and retrieved using multiple types of swabs. Swab type affected the total number of bacteria retrieved but had little effect on proportion of bacterial species collected ( $p=0.455$, by paired t-test). Mutant strains were observed for $E$. coli to determine contribution of surface features to fomite adhesion. Pili and flagella had greatest impact on retrieval from fomites with varied topography $\left(\right.$ ANOVA $\left._{(44,4)}=6.099 ; p=6.0 \times 10^{-4}\right)$, whereas surface chemistry and capsule chemistry had greatest impact on retrieval of species from fomites of different surface energies (ANOVA $\left.F_{(20,3)}=52.08, p=1.24 \times 10^{-9}\right)$. Adhesive properties of additional surface structures may need to be assessed and a more quantifiable study of fomite topography needs to be explored. Ultimately, a paradigm needs to be devised to make accurate comparisons of CFUs retrieved by swabbing surfaces for microbial contaminants.

Keywords: Bacterial Adhesion, Pili, Flagella, Swabbing, Fomites, CFUs.
\end{abstract}

*Correspondence: v-motz@onu.edu; 419-772-2063

(Received: 23 November 2019; accepted: 15 December 2019)

Citation: Vicki Abrams Motz, Linda Mull Young, Meredith E. Motz, and Suzanne C. Young, A Sticking Point in Assessing Bacteria Contamination: Adhesive Characters of Bacterial Specializations, Swab Features, and Fomite Surface Properties Skew Colony Counts, J Pure Appl Microbiol., 2019; 13(4):2533-2544. https://doi.org/10.22207/JPAM.13.4.68

(C) The Author(s) 2019. Open Access. This article is distributed under the terms of the Creative Commons Attribution 4.0 International License which permits unrestricted use, sharing, distribution, and reproduction in any medium, provided you give appropriate credit to the original author(s) and the source, provide a link to the Creative Commons license, and indicate if changes were made. 


\section{INTRODUCTION}

Swabbing of surfaces to determine bacterial load is an industry standard used by hospitals (Smith et al., 2013), clinics (Spratt et al., 2014), nursing homes (Vesley et al., 1987; Rouch and Marchese, 2017), organized sports (Davies et al., 2017; Dyer et al., 2018), forensic investigators (You et al., 2019) and food processors (Garayoa et al. 2017, Keeratipibul, 2017) among others. The resultant colony counts are used to determine food and water safety (Jarvis et al., 2007), make medical diagnoses (Kwon et al., 2012; Hsu et al., 2019), verify advertised over-the-counter dosages (Goldstein et al., 2013) and evaluate sterility of medical equipment (Chernecky and Waller, 2010; Maki et al., 1977).

Adhesion of bacteria to cell surfaces is a critical step in pathogenesis (Hori and Matsumoto, 2010). Surface components which promote adhesion include: flagella, chemotactic proteins, fimbrial adhesins, lipopolysaccharides and capsules (Willis and Whitfield, 2013). Due to these adhesive features, the surface properties of fomites to which microbes adhere and the swabs used for their retrieval (and subsequent release into media), counts from standard swabbing techniques may not be accurate representations of the contaminating microbial community. Additionally, many bacteria produce surface biosurfactants which can interfere with adhesion (Giri et al., 2019).

Role of protective external bacterial features in adhesion: capsules and glycocalyces

The capsular polysaccharides of many bacterial species, which prevent desiccation and promote virulence by avoiding degradation, appear to have variable effects on adhesion (Rubinchik et al., 2014; Barato et al., 2016; Xu et al., 2016). Capsules serve in electrostatic evasion of phagocytes (Willis and Whitfield, 2013). In E. coli, alteration of capsular carbohydrates has been linked to reduced toxicity (Di et al., 2017). Conversely, Staphylococcus epidermidis produces a negatively charged glycocalyx slime layer, which forms a hydrophobic biofilm as well as a fibrinogen binding protein, both of which have been implicated in adhesion to prosthetics (Nilsson, et al., 1998). Once microbes form biofilms on medical device surfaces, they are extremely difficult to remove (Lin et al., 2017).
Role of external cell wall bacterial structures: pili, flagella, and o-oligosaccharides

Pili come in a variety of shapes, locations, and functions; and multiple types can be found on the same cell. In E. coli, Type 1 pili (Kolenda et al., 2019) and P pili are well documented adhesion structures (Hori and Matsumoto, 2010) associated with uropathogenicity (Mulvey et al., 1998). The CFA-1 and CS pili are associated with enterotoxigenicity (Epler Barbercheck et al., 2018). Pili associated helical adhesion proteins and pilins have been linked to increased adhesion to host cell surfaces enhancing virulence (Epler Barbercheck et al., 2018). Flagella also promote adherence by acting as adhesins, and increase virulence due to motility associated pathogen spread (Duan et al., 2012). Mutant flagella or those inhibited by antiflagellin antibodies have significantly decreased adhesive properties (Giron et al., 2002; Roy et al., 2009). The negative charge associated with the o-oligosaccharide of the gram negative outer membrane electrostatically repels phagocytes, increasing bacterial virulence and affecting their ability to bind to different fomites (Anderson and Young, 2016). Because wild type E. coli makes use of all of these structures as virulence factors, mutant knockout strains missing specific external components make an ideal study model.

Fomite features influencing microbial adhesion

Fomite adhesive properties, including surface energy and topography, may also alter adherence. It has been shown that the intrinsic surface properties of different types of plastics affect both long and short term bacterial adhesion to their surfaces (Cai et al., 2019). Variations in roughness on a nanoscale and surface chemical heterogeneity further confound assessment of bacterial adhesion onto fomites (Bradford et al., 2018).

All surfaces have an inherent charge which creates weak charged interactions with other surfaces with which they come into contact. The smaller the structures (such as bacteria) and the more densely packed, the greater the number of small interactions that occur. These weak dipole-to-dipole like interactions constitute a van der Waal's bond, and increase adherence. This is a major component of Derjaguin-Landau-VerweyOverbeek (DLVO) theory, which relies upon weakly 
charged molecular interactions to explain the adhesive properties of cells (Hori and Matsumoto, 2010, Cai et al., 2019).

\section{Interaction of swabs and fomites}

Both the swab composition and the pattern of swabbing can impact the debonding of a bacterium from a surface and its subsequent attachment to a swab (Keeratipibu et al., 2017; You et al., 2019). This transfer is less likely if a swab has lower surface energy than the fomite surface or is being moved in the same direction as the microbe-surface bond. Although rougher topography increases the total surface area of a fomite, it may offer fewer available bonding sites if microbes are unable to access the crevices. This should result in easier bacterial transfer during swabbing. Conversely, if bacteria are sequestered in the crevices of a rough surface, they may be unreachable by swabbing, reducing retrievability. On skin, tape-stripping has been suggested as a comparable or even preferable method for bacterial retrieval to address some of these issues (Ogai et al., 2018).

Swab features influencing microbial adhesion

Polyester swabs are hydrophobic but may develop a negative static charge when rubbed on a surface during sampling (Maruf, 2019) which could result in electrostatic repulsion of negatively charged bacteria. Flocked nylon swabs have a brush-like texture which the manufacturer claims will better extricate surface microbes and a strand arrangement designed to use capillary action to maximize uptake (Becton Dickinson, 2019; Copan, 2019). While cotton swabs are considered neutral in generating a static charge, the fibers themselves have a net negative charge which could reduce microbial attachment (Cotton Fiber, 2012), increasing retrieval. You et al. (2019) found cotton swabs to be most effective in retrieving DNA samples of $E$. coli and $S$. aureus from hard surfaces. They also determined that wetting the swabs affected DNA retrieval; and called for a standardized sampling method.

Moisture regain values, which are a measure of absorptiveness, likely influence both bacterial adhesion to and release from swabs; and vary greatly between swab materials ( polyester $=0.4 \%$, cotton $=8.5 \%$, nylon $=4.0 \%$ ) (Polyester, 2012). Additionally, variations in the swab surface area and sampling technique may alter results and reduce the comparability of studies.

This investigation elucidated the impact of the following factors on accurately determining the composition of microbial communities sampled by surface swabbing: 1 ) the role of fomite surface properties, 2) the efficacy of swabs in bacterial retrieval and release to media (transfer from fomite to fomite) and 3) the role of external bacterial features in microbial adherence to a surface and subsequent resistance to removal by swabbing.

\section{MATERIALS AND METHODS Handling of bacteria}

See Table 1 for all bacterial species used in this investigation, their source, gram reaction and unique adhesive features. Streptococcus pneumoniae was grown for 18 hours in MuellerHinton broth (MH) at $37^{\circ} \mathrm{C}$ with $5 \% \mathrm{CO}_{2}$. All other cultures were grown for 18 hours in $\mathrm{MH}$ broth with agitation $(125 \mathrm{rpm})$ at $37^{\circ} \mathrm{C}$. Individual species were diluted to $0.5 \mathrm{McF}$ arland Standard (1.5 $\times 10^{8}$ cells per $\left.\mathrm{ml}\right)$. Because it is debonded so much more readily than other species in this study, Staphylococcus epidermidis was used at 0.05 McFarland Standard in mixed cultures to facilitate counting. Colony forming units (CFUs) of S. epidermidis were multiplied by 10 to generate comparable data to other species used.

Aliquots were applied to $5 \mathrm{~cm} \times 7.5 \mathrm{~cm}$ areas of sterilized fomites ( $\mathrm{N}=3$ for screening studies and as indicated for specific studies) and uniformly dispersed with a sterile cell spreader (USA Scientific, 2977-5500) to achieve a concentration of $2.5 \times 10^{6}$ cells per surface. After drying, surfaces were swabbed and extracted using the standard protocol.

\section{Handling of swabs}

Sterile swabs: nylon (COPAN-FLOQSwab ${ }^{\circledR}$; flocked), cotton (ULINE - Puritan), rayon (Thermo Fisher Scientific - Remel BactiSwab ${ }^{\circledR}$ ), foam (Thermo Fisher Scientific - Puritan), dacron (LOVEDAY - Puritan; knitted) and polyester (LOVEDAY - Puritan) were wetted with MH broth as dry swabbing reduces retrieval (Keeratipibul et al., 2017). Each contaminated area was first sampled using one side of the swab to vertically cover the entire surface, then the swab was flipped and the area was reswabbed horizontally before using 
Table 1. Bacterial species used in this investigation

\begin{tabular}{|c|c|c|c|c|}
\hline Bacterial species & Source & $\begin{array}{l}\text { Identifying } \\
\text { code }\end{array}$ & $\begin{array}{l}\text { Gram } \\
\text { stain }\end{array}$ & External feature \\
\hline Bacillus subtilis & Ward's & $470176-524$ & Positive & $\begin{array}{l}\text { Hard, glutamyl polypeptide } \\
\text { capsule }\end{array}$ \\
\hline Escherichia coli & Coli Genetic Stock Center & BW30388 & Negative & Wild type \\
\hline Escherichia coli & Coli Genetic Stock Center & BW30388 Strain 29667 & Negative & Fimbriae free mutant \\
\hline Escherichia coli & Coli Genetic Stock Center & BW30388 Strain 9024 & Negative & Flagella free mutant \\
\hline Escherichia coli & Coli Genetic Stock Center & BW30388 Strain 9671 & Negative & $\begin{array}{l}\text { o-oligosaccharide free } \\
\text { mutant }\end{array}$ \\
\hline Escherichia coli & Coli Genetic Stock Center & BW30388 Strain 11767 & Negative & Common pili free mutant \\
\hline Escherichia coli & Coli Genetic Stock Center & BW30388 Strain 7962 & Negative & Type I pili free mutant \\
\hline $\begin{array}{l}\text { Klebsiella } \\
\text { pneumoniae }\end{array}$ & ATCC & 13883 & Negative & Soft slime layer \\
\hline $\begin{array}{l}\text { Staphylococcus } \\
\text { epidermidis }\end{array}$ & ATCC & 12228 & Positive & Glycocalyx \\
\hline $\begin{array}{l}\text { Streptococcus } \\
\text { pneumoniae }\end{array}$ & ATCC & 49619 & Positive & Wild type \\
\hline $\begin{array}{l}\text { Streptococcus } \\
\text { pneumoniae }\end{array}$ & ATCC & 39987 & Positive & Capsule free mutant \\
\hline
\end{tabular}

the tip to swab the perimeter. Because swabbing pressure and technique can vary from person to person, one investigator conducted all of the swabbing.

Bacteria were extracted from the swabs using a standardized protocol. Swabs were extracted in $2 \mathrm{ml}$ of $\mathrm{MH}$ broth using an Eppendorf Thermoagitator at $37^{\circ} \mathrm{C}$ and $1,000 \mathrm{rpm}$ for 5 min. Spread plates of $\mathrm{MH}$ with $5 \%$ sheep red blood cells (SRBC) were inoculated with $10 \mu \mathrm{l}$ of extract and incubated at $37^{\circ} \mathrm{C}$ for 24 hours with $5 \% \mathrm{CO}_{2}$. Control plates with $10 \mu \mathrm{l}$ of each culture were prepared to ensure all strains exhibited equivalent growth. CFUs were visually quantified for plates exhibiting low counts and the Flash ' $N$ Go automated colony counter was used for plates with heavy growth to ensure accuracy.

\section{Handling of fomites}

For screening studies, $5 \mathrm{~cm} \times 7.5 \mathrm{~cm}$ $\left(37.5 \mathrm{~cm}^{2}\right)$ areas of untreated planed wood, plastic computer tower, acrylic wall paint, glass, aluminum flashing, wrestling mat squares (polyvinyl coated scrim) and ethylene-vinyl acetate (EVA) footwear soles were utilized (Table 2). Interaction of surface

Table 2. Surface energy and topography of sampled fomites

\begin{tabular}{lccc}
\hline Material & $\begin{array}{c}\text { Surface energy } \\
\text { (dynes) }\end{array}$ & Topography & Source \\
\hline Aluminum & 850 & smooth & Permabond, 2015 \\
Glass & 250 & smooth & Permabond, 2015 \\
ABS plastic & 42 & smooth & Permabond, 2015 \\
Acrylic paint on wall & 45 & rough & Raghavan, 2018 \\
Poly vinyl & 37 & rough & Permabond, 2015 \\
EVA & 33 & rough & Permabond, 2015 \\
Wood & $30-50$ & rough & Jankowska et al., 2018 \\
Plastics & $20-50$ & rough /smooth & Categorizing Surface Energy, 2019 \\
\hline Journal of Pure and Applied Microbiology & & 2536 &
\end{tabular}


specialization with fomite type was assessed using aluminum (high surface energy (850 dynes); smooth topography), polyvinyl film (low surface energy (30-34 dynes); smooth topography) and polyvinyl coated scrim wrestling mat (low surface energy (30-34 dynes); rough topography) ( $\mathrm{N}=6$ for each surface).

Surfaces were cleaned and disinfected with acetone, then ethanol and a subsequent 15 min UV light treatment. Because it was determined that this decontaminating process could alter fomite surfaces, follow up studies used fresh $5 \mathrm{~cm}$ $x 7.5 \mathrm{~cm}$ surfaces of wrestling mat, acrylonitrile butadiene styrene (ABS) plastic (McMaster-Carr) (Permabond, 2015) and glass, cleaned by running under $\mathrm{DH}_{2} \mathrm{O}$ stream for $60 \mathrm{sec}$, followed by $15 \mathrm{~min}$ exposure to UV radiation.

\section{RESULTS AND DISCUSSION Initial screening of fomites}

S. epidermidis, with no specialized adhesive features, was used to screen fomites. Bacteria were applied to untreated planed wood, plastic computer tower, acrylic painted wall, glass, aluminum flashing, wrestling mat squares, and ethylene-vinyl acetate footwear. Recovery from fomites showed significant variation based on the surface. Greatest retrieval was from the acrylic painted wall and least retrieved was from the porous wood surface (Fig. 1). Similar results were seen by Milks and Goodwin (2018) who inoculated different surface types with a variety of bacteria and found that all species were more easily retrieved from a smooth ethylene vinyl acetate surface than from any other fomite material they tested.

\section{Initial screening of bacteria}

Bacillus subtilis, Streptococcus pneumoniae, Streptococcus pneumoniae capsule free mutant, Escherichia coli wild type (with pili, flagella, fimbriae, and capsule), E. coli

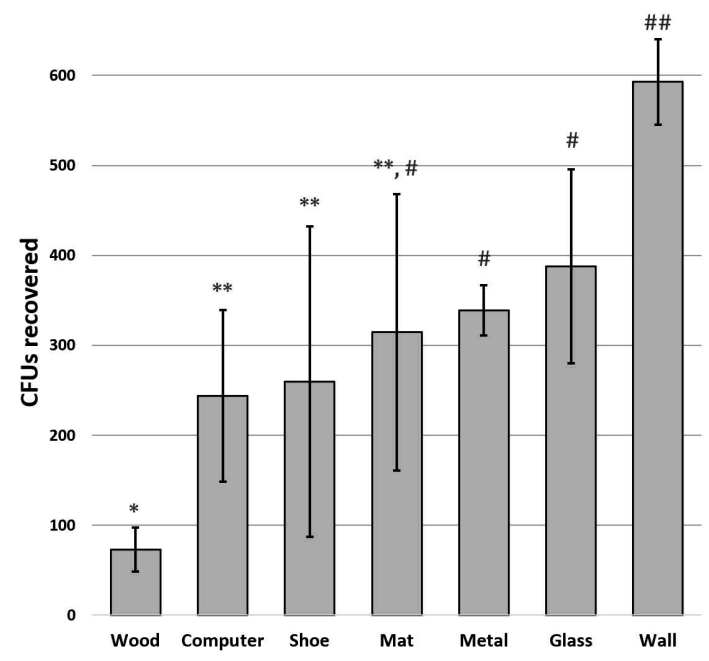

Fig. 1. Retrieval of S. epidermidis differed significantly from various surfaces. Graph shows mean CFUs+/-SD. Significance determined by ANOVA $F_{(14,6)}=4.49 \mathrm{p}=9.0$ $x 10^{-3}$; asterisk designations indicate significance by t-test at $p<0.05$.

fimbriae free mutant, Klebsiella pneumoniae, and Staphylococcus epidermidis were applied to polyvinyl coated scrim wrestling mat (low surface energy (30-34 dynes); rough topography) which tested in the mid-range for adhesion (above). $S$. pneumoniae (both wild type and a capsule free mutant strain) were poorly recovered (less than $0.4 \%$ ) on all surfaces. B. subtilis, with its hard, glutamyl polypeptide capsule (Thorne, 1993), did not differ significantly from S. pneumoniae. The large slime layer capsule of $K$. pneumoniae was less likely to remain firmly attached to a test surface as evidenced by approximately $2 \%$ retrieval. $S$. epidermidis with no adhesive specializations beyond a glycocalyx demonstrated the greatest retrieval of all bacterial species from the tested surfaces ( 2.8\%) (Fig. 2). The issue of comparison of bacterial types in mixed cultures is exacerbated by the fact that bacteria grow at different rates (Liang et al., 2017).

Table 3. E. coli knockout strains used in this study

\begin{tabular}{lll}
\hline \multicolumn{1}{c}{ Knockout } & \multicolumn{1}{c}{ Functional change } \\
\hline $\begin{array}{lll}\text { CGSC:9024 } \\
\text { CGSC:9671 }\end{array}$ & $\begin{array}{l}\text { loss of rod assembly protein } \\
\text { no o-oligosaccharide in outer } \\
\text { membrane }\end{array}$ & $\begin{array}{l}\text { non-functional flagella (Moens and Vanderleyden, 1996) } \\
\text { reduces net negative charge/adhesive ability }\end{array}$ \\
$\begin{array}{ll}\text { CGSC:11767 } \\
\text { no common pili } \\
\text { no type 1 pili }\end{array}$ & $\begin{array}{l}\text { reduces biofilm formation (Stacey et al., 2014) } \\
\text { lack of associated adhesins (Epler-Barberchek et al., 2018) }\end{array}$ \\
\hline Journal of Pure and Applied Microbiology & 2537 & www.microbiologyjournal.org
\end{tabular}




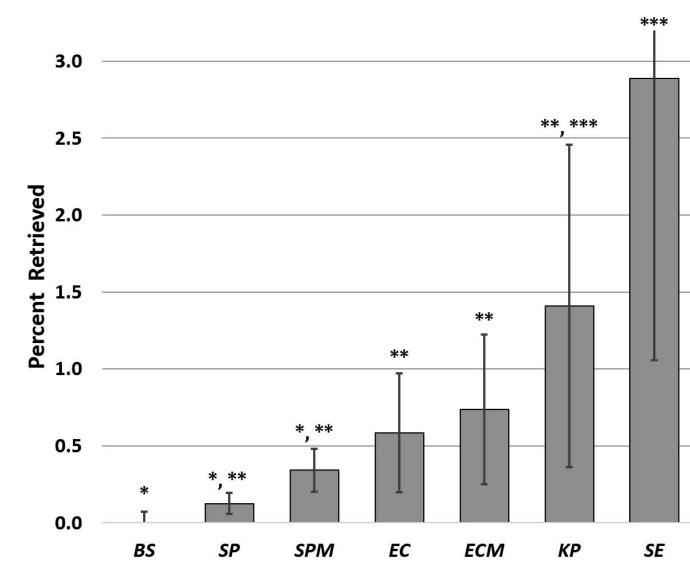

Fig. 2. Comparative retrieval of multiple bacterial species from a polyvinyl surface $\mathrm{N} \geq 8$. Graph shows mean CFUs + - SD. Significance determined by ANOVA $F_{(97,7)}=9.55$, $\mathrm{p}=2.6 \times 10^{-10}$; asterisk designations indicate significance by t-test at $p<0.05$. $B S=B$. subtilis, $S P=S$. pneumoniae, $S P M=S$. pneumoniae mutant - no capsule, $E C=E$. coli, $E C M=E$. coli fimbriae free mutant, $K P=K$. pneumoniae, $S E=S$. epidermidis.

\section{Initial screening of swabs}

Cotton, polyester and nylon swabs retrieved significantly greater numbers of wild type E. coli from wrestling mats than foam, dacron, or rayon swabs $\left(F_{17.5}=3.2520, p=0.043\right)$ (Fig. 3). This

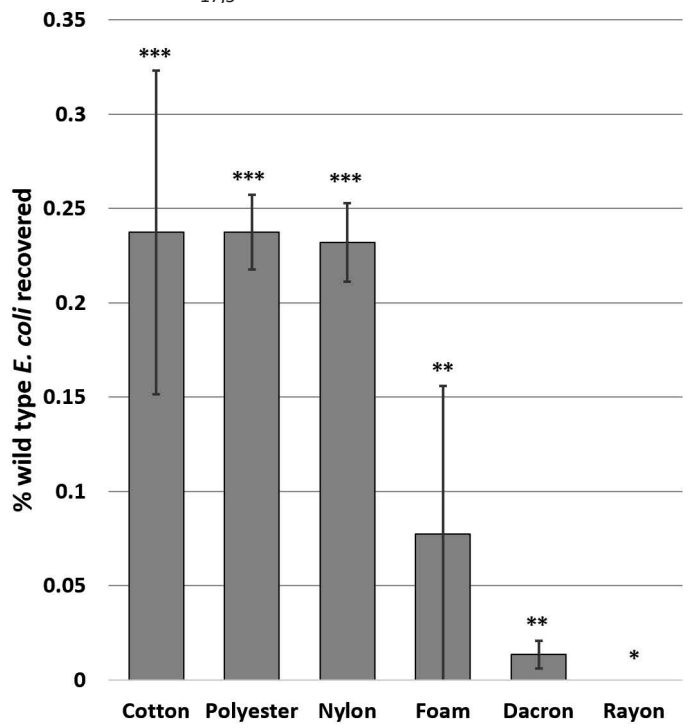

Fig. 3. Significant differences in ability of different swabs to retrieve $E$. coli from a polyvinyl surface with low surface energy and high topography. Graph shows mean CFUs +/- SE. Significance determined by ANOVA $\mathrm{F}_{(17,5)}=3.25, \mathrm{p}=4.0 \times 10^{-2}$; asterisks indicate significant differences by $\mathrm{t}$ - test at $\mathrm{p}<0.05 . S P=S$. pneumoniae, $B S$ $=B$. subtilis, $K P=K$. pneumoniae. is consistent with the findings of Keeratipibul et al. (2017) who also found cotton to be the most effective. Cotton swabs of all brands tested had the highest mass of swabbing material, thus the efficacy of the cotton may be due to the amount/ surface area of the swabbing material rather than to the nature of the cotton fiber. It should be noted that swabbing allows for quantification and identification of only culturable bacteria. Young et al. (2018) compared retrieval of nonculturable bacteria to culturable species and found a tenfold increase in bacterial types identified with the DNA mi-Seq system over standard swabbed cultures. Since this type of testing is generally cost prohibitive and only culturable species are detected with commonly used methods, it can be presumed that a huge percentage of the bacterial community goes unobserved in the majority of analyses (Paxton, 2004).

Protective external structures: capsules and glycocalyx

To compare the effect of capsule type, S. pneumoniae (gram positive; encapsulated wild type), B. subtilis (gram positive; large capsule), and $K$. pneumoniae (gram negative; soft slime layer) were inoculated onto wrestling mat surfaces and retrieved using rayon swabs (Thermo Fisher Scientific-Remel BactiSwab). The soft slime layer of $K$. pneumoniae composed of loosely bound exopolymeric substances (Hori and Matsumoto, 2010) appears to confer less adhesion than harder encapsulated species which are composed of more tightly bound exopolymeric substances. (Fig. 4). The glutamyl polypeptide found in the capsule of B. subtilis (Liu et al., 2013) can be degraded by glutamyl hydrolase also found in $B$. subtilis (Ashiuchi et al., 2003). This natural capsule degradation increases hydrophobicity which has been shown to increase bacterial adhesion (Bartley et al., 2013). The ability of bacteria to form biofilms is similarly influenced by the composition of the exopolymeric substances secreted (Danese et al., 2000). Thus, species specific capsule composition must be considered when evaluating retrieval of different encapsulated bacteria under the same conditions.

External cell wall structures : flagella, pili and o-oligosaccharides

The impact of attachment features was differentiated utilizing a single species, E. coli 


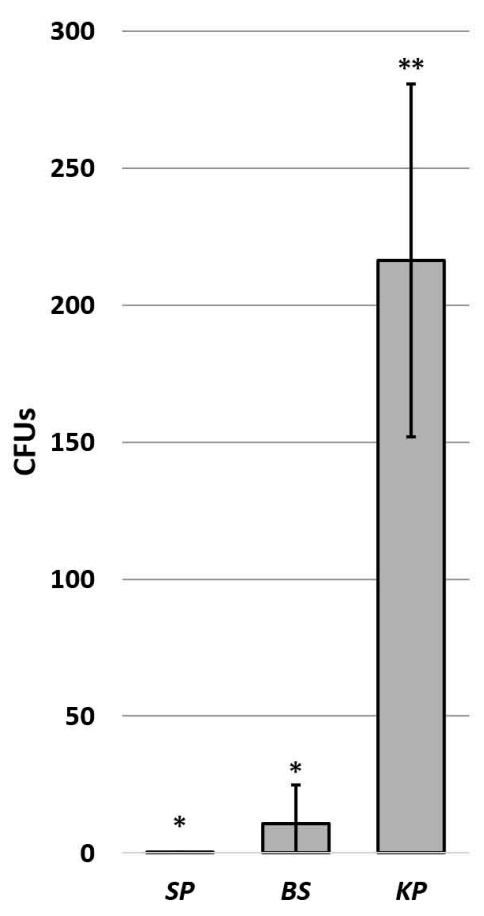

Fig. 4. Effect of capsule type on retrievability of bacteria from a mat surface. Graph shows mean CFUs +/- SD. Significance determined by ANOVA $\mathrm{F}_{(20,3)}=52.08, \mathrm{p}=$ $1.24 \times 10^{-9}$; asterisks indicate significance at $p<2.0 \times$ $10^{-4} ; \mathrm{N}=6$.

(Coli Genetic Stock Center; CGSC BW30388) with associated knockout strains (Table 3). Fig. 5.

Bacteria were inoculated onto wrestling mats (low surface energy (30-34 dynes); rough topography), aluminum (high surface energy (850 dynes); smooth topography), and ABS plastic (low surface energy (42 dynes); smooth topography). There was a significant reduction in surface adhesion of mutant $E$. coli when compared to the wild type (Fig. 5). Different types of pili have different structures and functions (Proft and Baker, 2009). On all surfaces tested, the trend observed indicates that loss of common pili causes the greatest decrement in adhesion. As expected, microbes lacking functional flagella have decreased adhesive properties, confirming findings of Giron et al., 2002 and Duan et al., (2012). Type I pili have relatively weaker receptor bonding, unless subjected to tensile stressors like urine flow (Hospenthal et al., 2017) thus mutations of type I pili have less impact on adhesion. Although total CFUs varied, the trend in retrievability of mutants was not significantly different between the fomites.

\section{Combined effects of fomite and swab type on} retrieval of $E$. coli

For all strains of $E$. coli, retrieval from aluminum (very high surface energy (850 dynes); smooth topography) had a similar adhesive pattern to the ABS (low surface energy (30-34 dynes); smooth topography) $(p=0.81)$ which differed significantly from retrieval from the mat (low surface energy (30-34 dynes); rough topography) $(p=0.02)$.

When all bacteria were considered together, cotton swabs retrieved 3.4 times more bacteria than rayon swabs. However, the cotton swab tips weighed an average of $0.034 \pm 0.006 \mathrm{~g}$, which is 4.25 times the weight of the rayon tips $(0.008 \pm 0.001 \mathrm{~g})$. When swab weight differential is factored out, there is no significant difference between the swab materials on retrievability for cotton vs rayon $(p=0.13)$. Potentially surface area of swabs may alter results but was deemed unquantifiable for this study.

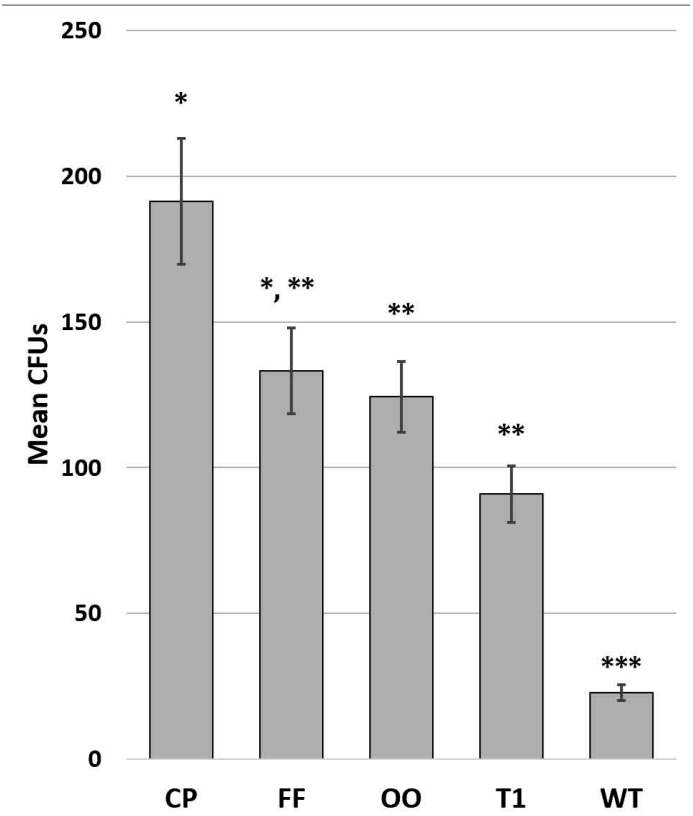

Fig. 5. Combined counts of $E$. coli mutant counts for 3 fomite surfaces. Graph shows mean +/-SE. Significance determined by ANOVA $\mathrm{F}_{(44,4)}=6.099 ; \mathrm{p}=6.0 \times 10^{-4}$; asterisks indicate significant differences by t-test at $\mathrm{p}<0.05 ; \mathrm{N}=18$ per species. $\mathrm{CP}=$ no common pili, $\mathrm{FF}=$ no functional flagella, $\mathrm{OO}=$ no o-oligosaccharides, $\mathrm{T} 1=$ no type 1 pili, WT = wild type. 
Both the trend in adhesion to surfaces and the insignificant variation in swab type was confirmed using wild type $E$. coli collected with nylon (flocked COPAN - FLOQSwab ${ }^{\circledR}$ ) and cotton (ULINE - Puritan) swabs ( $p=0.455$ by paired t-test) and replacing the high surface energy, smooth topography aluminum with glass which has similar high surface energy, smooth topography surface characteristics (Fig. 6). This change was necessary as metals are susceptible to surface change during chemical decontamination and bacterial adhesion to metals appears to depend on the terminating polyelectrolyte layer (Kovacevic et al., 2016). Fig. 6.

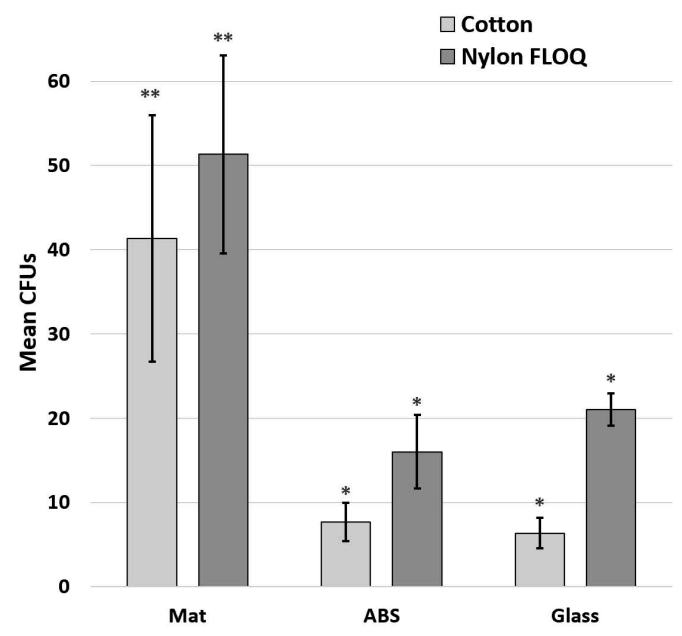

Fig. 6. Retrieval of wild type E. coli from different fomites using two swab types. Graph shows mean +/$\mathrm{SE}$. Significance determined by ANOVA $\mathrm{F}_{(20,3)}=5.23, \mathrm{p}=$ $7.8 \times 10^{-3}$; asterisks indicate statistical significances at $\mathrm{p}<0.05$ by t-test. $\mathrm{N}=6$ for each fomite.

\section{Effects of fomite and swab type on retrieval of mixed cultures}

Mixed cultures of wild type $E$. coli, wild type S. pneumoniae and S. epidermidis were inoculated onto mat, $A B S$, and glass surfaces and retrieved with cotton and nylon FLOQswabs ${ }^{\circledR}$. Swab type made no significant difference in retrieval of different bacteria from varied surfaces $(p=0.455$ by paired t-test). However, there was a distinct difference in collection of bacterial species $\left(F_{51,2}\right.$ $=4.91, p=0.011$ ) that varies with fomite surface $\left(F_{(15,2)}=17.60, p=0.0001\right) . S$. epidermidis (no attachment specializations) was more efficiently retrieved from $A B S$ and mat surfaces which have low surface energy than the $E$. coli or the $S$. pneumoniae (Fig. 7). S. pneumoniae (negatively charged capsule) was most easily retrieved from the high surface energy glass. E. coli with its many adhesive factors was most difficult to remove from smooth surfaces (Fig. 8).

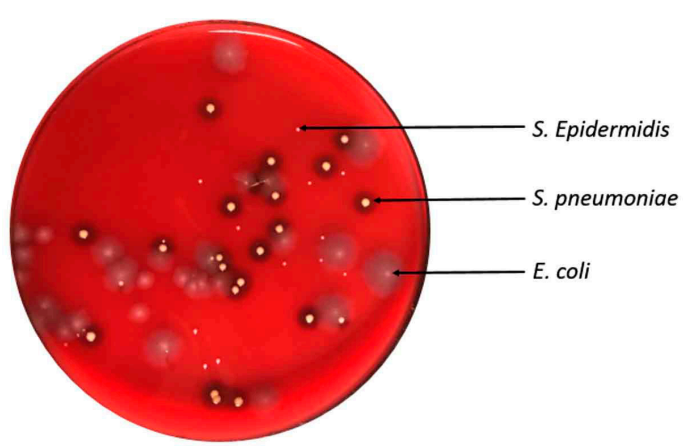

Fig. 7. Mixed culture retrieved from ABS with cotton swab. E. coli and S. pneumoniae at 0.5 McFarland Standard, S. epidermidis at 0.05 McFarland Standard.

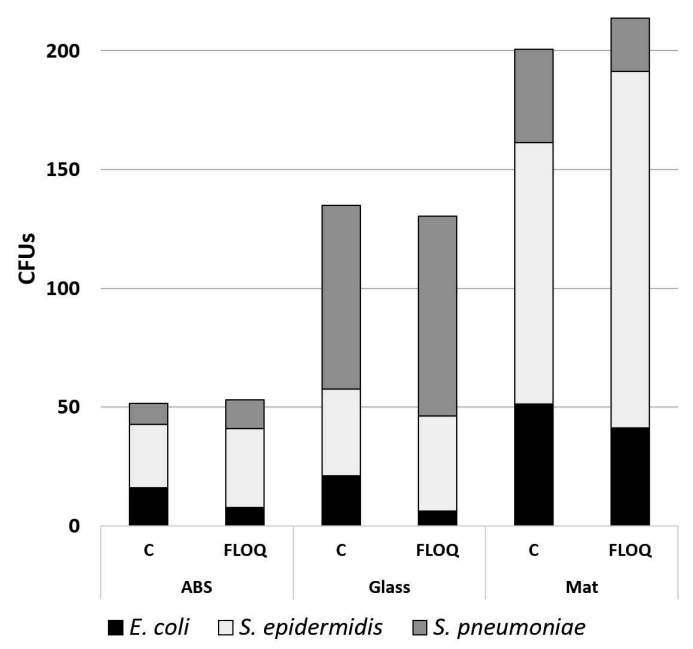

Fig. 8. Effects of surface and swab adhesive properties on retrieval of bacterial species with different adhesive features. $\mathrm{N}=6$. C. cotton, FLOQ - nylon FLOQSwabs ${ }^{\circledR}$.

\section{CONCLUSIONS}

Swab composition appears to have a minimal effect on microbial retrieval, with swab mass and surface area having greater importance to the total number of microbes retrieved. However, importantly, proportion of different species retrieved does not appear to be skewed by swab type. Bacterial surface specializations, fomite topography and fomite surface energy appear to 
interact in bacterial adhesion to and retrieval from surfaces. In species relying on adhesive structures such as pili and flagella, rough topography decreases adhesion and also decreases the portions of the surfaces contacted by swabs. Even if a bacterium in a surface depression could debond easily, a swab might be unable to contact it for removal. In species for which bonding is related to microbial surface chemistry and features such as charged capsules, the fomite surface energy appears to be a significant factor in adhesion and retrieval. The surface energy of the bacteria themselves was not considered and measuring bacterial surface energy has proven difficult (Hori and Matsumoto, 2010). Of clinical note, the tendency to develop smooth surfaces for objects, such as medical equipment and surgical implants with the goal of reducing adhesion may, in practice, be counter to that objective as smooth, defect-free surfaces increase bacterial adhesion (Bazaka et al., 2018).

Although swabbing is the traditional method of sampling in both clinical and commercial settings, this study indicates that results obtained in this manner do not accurately reflect contaminating microbial communities. Characteristics of bacterial surfaces, fomites, and swabs, all appear to affect bacterial retrieval. Consequently, the standard method of directly comparing CFUs of retrieved bacteria to one another appears to be invalid.

\section{ACKNOWLEDGEMENTS}

The authors would like to thank Dr. Rod Anderson and appreciate the contributions of Alyson Milks and Paige Goodwin to the laboratory work. This research has been funded by the Department of Biological and Allied Health Sciences, Ohio Northern University, Ada. OH.

\section{CONFLICT OF INTEREST}

The authors declare that there is no conflic of interest.

\section{FUNDING}

This work was internally funded by the Department of Biological and Allied Health Sciences at ONU - no grant funding was used.

\section{AUTHOR'S CONTRIBUTION}

VAM, LMY, MEM and SCY designed research. VAM, LMY and SCY performed experiment and obtained data. VAM, LMY and MEM analyed data. VAM, LMY, MEM and SCY wrote the manuscript and apporved it for publication.

\section{DATA AVAILABILITY}

We have all of the raw data in spread sheets should someone need to see it.

\section{ETHICS STATEMENT}

All text, data, figures and tables are completely original. All supportive information from sources other than this laboratory has been cited in the text and included in the literature cited section. None of the authors have any conflict of interest or any affiliation or involvement which could be a potential source of bias, nor would any of us benefit financially from its publication. No animals or human subjects were used in this research.

\section{REFERENCES}

1. Anderson R P, Young L M. Visualizing Microbiology, 2016, pp. 91-92. $1^{\text {st }}$ Ed. Wiley \& Sons, Inc., Hoboken, New Jersey.

2. Ashiuchi M, Nakamura H, Yamamoto T, Kamei T, Soda K, Park C. Poly- $\gamma$-glutamate depolymerase of Bacillus subtilis: production, simple purification and substrate selectivity. J. Mol. Catal. B-Enzym., 2003; 23: 249-255. https://doi.org/10.1016/S1381-1177(03)00087-0

3. Barato P, Martins ER, Vasquez GM, Ramirez M, Melo-Cristino J, Martinez N, Iregui C. Capsule impairs efficient adherence of Streptococcus agalactiae to intestinal epithelium in tilapias Oreochromis $s p$. Microbial Pathogenesis, 2016; 100: 30-36. https://doi. org/10.1016/j.micpath.2016.08.040

4. Bartley SN, Tzeng YL, Heel K, Lee CW, Mowlaboccus S. Attachment and invasion of Neisseria meningitidis to host cells is related to surface hydrophobicity, bacterial cell size and capsule. PLOS ONE, 2013; 8(2): e55798. https://doi.org/10.1371/journal.pone.0055798

5. Bazaka K, Jacob MV, Crawford RJ, Ivanova EP. Plasmaassisted surface modification of organic biopolymers to prevent bacterial attachment. Acta Biomaterialia, 2011; 7: 2015-2028. https://doi.org/10.1016/j. actbio.2010.12.024

6. Becton Dickinson and Company. 2019. https://www. bd.com/en-us/offerings/capabilities/specimencollection/swab-based-specimen-collection/bdflocked-swabs, 20 january 2019. 
7. Bradford S A, Sasidharan S, Kim H, Hwang G Comparison of types and amounts of nanoscale heterogeneity on bacteria retention. Frontiers in Environmental Science, 2018; 6:56. https://doi. org/10.3389/fenvs.2018.00056

8. Cai L, Wu D, Xia J, Shi H, Kim, H. Influence of physiocochemical surface properties on the adhesion of bacteria onto four types of plastics. Science of the Total Environment, 2019; 671: 1101-1107. https://doi. org/10.1016/j.scitotenv.2019.03.434

9. Categorizing Surface Energy. 3M Science of Adhesion Educational Series. https://www.3m.com/3M/en_US/ bonding-and-assembly-us/resources/science-ofadhesion/categorizing-surface-energy/, Accessed 20 january, 2019.

10. Chernecky C, Waller J. Comparison of bacterial CFUs in five intravenous connectors. Clinical Nursing Research, 2010; 19: 416-428. https://doi. org/10.1177/1054773810375110

11. Copan. https://www.copanusa.com/sample-collectiontransport-processing/floqswabs/, Accessed Accessed 5 december, 2019.

12. Cotton Fiber. 2012. Cotton Fiber / Physical and Chemical Properties of Cotton. http://textilefashionstudy.com/ cotton-fiber-physical-and-chemical-properties-ofcotton/, Accessed 20 august, 2019.

13. Danese N, Pratt L A, Kolter R. Exopolysaccharide production is required for development of Escherichia coli K-12 biofilm architecture. Journal of Bacteriology, 2002; 182: 3593-3596. https://doi.org/10.1128/ JB.182.12.3593-3596.2000

14. Davies HD, Jackson MA, Rice SG. Infectious diseases associated with organized sports and outbreak control committee on infectious diseases, council on sports medicine and fitness. American Academy of Pediatrics Clinical Report, 2017: 140(4). https://doi.org/10.1542/ peds.2017-2477

15. Di R, Vakkalanka MS, Onumpai C, Chau HK, White A, Rastall RA, Yam K, Hotchkiss AT Jr. Pectic oligosaccharide structure-function relationships: prebiotics, inhibitors of Escherichia coli 0157:H7 adhesion and reduction of Shiga toxin cytotoxicity in HT29 cells. Food Chemistry, 2017; 227: 245-254. https://doi.org/10.1016/j. foodchem.2017.01.100

16. Duan Q, Zhou M, Zhu L, Zhu G. Flagella and bacterial pathogenicity. Journal of Basic Microbiology, 2013; 53(1): 1-8. https://doi.org/10.1002/jobm.201100335

17. Dyer HR, Davis A, Peters B, Beaschler R, Young LM, Motz V A, Krynak K L. Assessment of cleaning product efficacy on collegiate wrestling mats [Abstract]. In The Ohio Journal of Science, 2018; 118(1): JIT5.

18. Epler Barbercheck CR, Bullitt E, Andersson M. Bacterial adhesion pili. Sub-Cellular Biochemistry, 2018; 87:1-18. https://doi.org/10.1007/978-981-107757-9_1

19. Garayoa R, Abundancia C, Diez-Leturia M, IsabelVitas A. Essential tools for food safety surveillance in catering services: on-site inspections and control of high risk cross-contamination surfaces. Food Control, 2017; 75: 48-54. https://doi.org/10.1016/j. foodcont.2016.12.032

20. Giri SS, Ryu EC, Sukumaran V, Park SC. Antioxidant, antibacterial, and anti-adhesive activities of biosurfactants isolated from Bacillus strains. Microb. Pathog., 2019; 132: 66-72, doi: 10.1016/j. micpath.2019.04.035. Epub 2019 Apr 24. https://doi. org/10.1016/j.micpath.2019.04.035

21. Giron, JA, Torres, AG, Freer, E, Kaper, JB. The flagella of enteropathogenic Escherichia coli mediate adherence to epithelial cells. Molecular Microbiology, 2002; 44: 361-379. https://doi.org/10.1046/j.13652958.2002.02899.x

22. Goldstein EJ, Citron DM, Claros MC, Tyrrell K L. Bacterial counts from five over-the-counter probiotics: are you getting what you paid for? Anaerobe, 2014; 25: 1-4. https://doi.org/10.1016/j.anaerobe.2013.10.005

23. Hori K, Matsumoto S. Review: Bacterial adhesion: from mechanism to control. Biochemical Engineering Journal, 2010; 48(3): 424-434. https://doi. org/10.1016/j.bej.2009.11.014

24. Hospenthal, MK, Costa TR, Waksman G. A comprehensive guide to pilus biogenesis in Gramnegative bacteria. Nature Review, 2017; 15: 365-379. https://doi.org/10.1038/nrmicro.2017.40

25. Hsu M-S, Liao C-H, Fang C-T. Role of nasal swab culture in guiding antimicrobial therapy for acute cellulitis in the era of community-acquired methicillin-resistant Staphylococcus aureus: A prospective study of 89 patients. Journal of Microbiology Immunology and Infection, 2019; 52(3):494-497. https://doi. org/10.1016/j.jmii.2019.04.001

26. Jankowska A, Zbiec M, Kozakiewicz P, Koczan G, Olenska $S$, Beer P. The wettability and surface free energy of sawn, sliced and sanded European oak wood. Ciencia y tecnologia, 2018; 20(3): 443 - 454, doi: 10.4067/ S0718-221X2018005031401 ISSN impresa 0717-3644 ISSN online 0718-221X. https://doi.org/10.4067/ S0718-221X2018005031401

27. Jarvis B, Hedges A I, Corry, J. Assessment of measurement uncertainty for quantitative methods of analysis: comparative assessment of the precision (uncertainty) of bacterial colony counts. International Journal of Food Microbiology, 2007; 116: 44-51. https://doi.org/10.1016/j.ijfoodmicro.2006.12.037

28. Keeratipibul S, Laovittayanurak T, Pornruangsarp O, Chaturongkasumrit $\mathrm{Y}$, Takahashi $\mathrm{H}$, Techaruvichit $\mathrm{P}$. Effect of swabbing techniques on the efficiency of bacterial recovery from food contact surfaces. Food Control, 2017; 77: 139-144. https://doi.org/10.1016/j. foodcont.2017.02.013

29. Kolenda R, Ugorski M, Grzymajlo K. Everything You Always Wanted to Know About Salmonella Type 1 Fimbriae, but Were Afraid to Ask. Frontiers in Microbiology, 2019; 10: 1017. https://doi.org/10.3389/ fmicb.2019.01017

30. Kovacevic D, Pratnekar R, Torkar KG, Salopek J, Dra ic G, Abram A, Bohinc K. Influence of Polyelectrolyte Multilayer Properties on Bacterial Adhesion Capacity. Polymers 2016; 8: 345; https://doi.org/10.3390/ polym8100345 
31. Kwon J, Fausone M, Du H, Robicsek A, Peterson, L. Impact of laboratory-reported urine culture colony counts on the diagnosis and treatment of urinary tract infection for hospitalized patients. American Journal of Clinical Pathology, 2012; 137: 778-784. https://doi. org/10.1309/AJCP4KVGQZEG1YDM

32. Liang J, Liu F, Deng J, Li M, Tong M. Efficient bacterial inactivation with $\mathrm{Z}$ scheme $\mathrm{Agl} / \mathrm{Bi} 2 \mathrm{MoO} 6$ under visible light irradiation. Water Resources, 2017; 123: 632-641. https://doi.org/10.1016/j.watres.2017.06.060

33. Lin QK, Xu X, Wang Y, Wang B, Chen H. Antiadhesive and antibacterial polysaccharide multilayer as IOL coating for prevention of postoperative infectious endophthalmitis International Journal of Polymeric Materials and Polymeric Biomaterials, 2017; 66(2): 97-104. https://doi.org/10.1080/00914037.2016.11 90925

34. Liu X, Liu F, Liu S, Li H, Ling P, Zhu X. Poly-g-glutamate from Bacillus subtilis inhibits tyrosinase activity and melanogenesis. Applied Microbiology and Biotechnology, 2013; 97(22): 9801-9809. doi:10.1007/ s00253-013-5254-6. PMID 24077684. https://doi. org/10.1007/s00253-013-5254-6

35. Maki D, Weise D, Sarafin H. A semiquantitative culture method for identifying intravenous-catheter related infection. New England Journal of Medicine, 1977; 296: 1305-1309. https://doi.org/10.1056/ NEJM197706092962301

36. Maruf MR. https://www.fibre2fashion.com/industryarticle/7146/cotton-clothing-comfort-compared-topolyester?page=3, Accessed 20 january, 2019.

37. Milks A, Goodwin P, Young L M, Motz V A. Validity of swabbing fomites to determine load and the influence of external bacterial specializations [Abstract]. InThe Ohio Journal of Science, 2018; 118(1): JIT-8.

38. Moens S, Vanderleyden J. Functions of bacterial flagella. Crit Rev Microbiol, 1996; 22(2): 67-100. https://doi.org/10.3109/10408419609106456

39. Mulvey MA, Lopez-Boado YS, Wilson CL, Roth R, Parks WC, Heuser J, Hultgren S J. Induction and evasion of host defenses by type 1-piliated uropathogenic Escherichia coli. Science, 1998; 282: 1494-1497. https://doi.org/10.1126/science.282.5393.1494

40. Nilsson M, Frykberg L, Flock JI, Pei L, Lindberg M, Guss B. A fibrinogen-binding protein of Staphylococcus epidermidis. Infection and Immunity, 1998; 66(6): 2666-2673. https://doi.org/10.1128/IAI.66.6.26662673.1998

41. Ogai K, Nagase $S$, Mukai K, luchi T, Mori Y, Matsue M, Sugitani K, Sugama J, Okamoto S. A Comparison of Techniques for Collecting Skin Microbiome Samples: Swabbing Versus Tape-Stripping. Frontiers in Microbiology, 2018; https://doi.org/10.3389/ fmicb.2018.02362

42. Paxton, A. 2004. http://www.captodayonline.com/ Archives/feature_stories/0804Swabs.html. Accessed 23 october, 2019.

43. Permabond Surface Energy \& Wetability. https:// www.permabond.com/2015/01/07/surface-energy- wetability/ Accessed 18 august, 2019.

44. Polyester. 2012. polyester-physical-and-chemicalproperties-of-polyester http://textilefashionstudy. $\mathrm{com} /$ polyester-physical-and-chemical-properties-ofpolyester/ Accessed 20 january, 2019.

45. Raghavan V. 2014. Basics of wetting and adhesion. http://oldsite.justpaint.org/jp31/jp31article5.php. Accessed 27 october, 2019.

46. Rouch M, Marchese G. Evaluation of potential fomites in senior nursing facility and rehabilitation unit [Abstract]. In The Ohio Journal of Science 2017; 117(1): A25.

47. Roy K, Hilliard G M, Hamilton D J, Luo J. Enterotoxigenic Escherichia coli EtpA mediates adhesion between flagella and host cells. Nature, 2009; 457: 594-598.49. https://doi.org/10.1038/nature07568

48. Rubinchik S, Seddon AM, Karlyshev AV. A negative effect of Campylobacter capsule on bacterial interaction with an analogue of a host cell receptor. BMC Microbiology, 2014; 14: 141 https://doi.org/10.1186/1471-2180-14141

49. Smith PW, Sayles H, Hewlett A, Cavalieri RJ, Gibbs SG, Rupp ME. A study of three methods for assessment of hospital environmental cleaning. Healthcare Infection, 2013; 8(2): 80-85. https://doi.org/10.1071/HI13001

50. Spratt G, Levine D, Tillman L. Physical therapy clinic therapeutic ultrasound equipment as a source for bacterial contamination Henry Physiotherapy Theory and Practice, 2014; 30(7): 507-511 2014 Informa Healthcare USA, Inc. https://doi.org/10.3109/09593 985.2014.900836

51. Thongsomboon W, Serra DO, Possling A, Hadjineophytou C, Hengge R, Cegelski L. Phosphoethanolamine cellulose: a naturally produced chemically modified cellulose. Science. 2018; 359(6373): 334-338. https:// doi.org/10.1126/science.aao4096

52. Thorne CB. Chapter 8 : Bacillus anthracis, 1993, pp 113124. In Sonenshein, Abraham L. and Hoch, James A. and Losick, Richard(eds), Bacillus subtilis and Other GramPositive Bacteria, American Society of Microbiology, Washington D.C. doi:10.1128/9781555818388.ch8. DOI 10.1128/9781555818388.ch8.

53. Vesley D, Klapes NA, Benzow K, Le CT. Microbiological evaluation of wet and dry floor sanitization systems in hospital patient rooms. Applied and Environmental Microbiology, 1987; 53(5): 1042-1045 00992240/87/051042-04. https://doi.org/10.1128/ AEM.53.5.1042-1045.1987

54. Willis LM, Whitfield C. Structure, biosynthesis, and function of bacterial capsular polysaccharides synthesized by $A B C$ transporter-dependent pathways. Carbohydrate Research, 2013; 378: 35-44. https://doi. org/10.1016/j.carres.2013.05.007

55. Xu B, Pei X, Su Y, Ma Z, Fan H. Capsule of Streptococcus equi subsp. zooepidemicus hampers the adherence and invasion of epithelial and endothelial cells and is attenuated during internalization. FEMS Microbiology Letters, 2016; 363(16); PMID: 27388015 https://doi. org/10.1093/femsle/fnw164 
56. Youa HS, Lee SH, Ok Y J, Kanga HG, Sung HJ, Lee JY, Kang SS, Hyuna SH. Influence of swabbing solution and swab type on DNA recovery from rigid environmental surfaces. Journal of Microbiological Methods, 2019; 161: 12-17. https://doi.org/10.1016/j. mimet.2019.04.011
57. Young LM, Kohls B, Davis A, Krynak K, Beaschler RE, Dyer $\mathrm{H}$, Motz VA. Clean handsא healthy wrestlers: Efficacy of hand cleaning in reducing bacterial load during wrestling competitions. Health Science Research, 2018; 5(2): 43-49. 